\title{
OPINIÃO
}

\section{As patentes das universidades públicas}

\author{
Renato Dagnino* \\ Rogério Bezerra da Silva**
}

As universidades públicas brasileiras superaramarm as empresas em solicitações de patentes junto ao Instituto Nacional de Propriedade Intelectual. E a Unicamp é a campeã. Há professores que comemoram! Eles consideram que patentes registradas pelas universidades são bons indicadores de inovação e aumentam a competitividade do país. E defendem que elas sejam incentivadas como tem feito a Unicamp, dado que podem gerar benefícios econômicos para a universidade e, indiretamente através de empresas que venham a utilizálas, para a sociedade que a mantém.

Outros não aceitam a via do "mercado", mas argumentam que se as universidades não patentearem os conglomerados multinacionais se apossarão do conhecimento desenvolvido; e isto não é justo. Citando quase sempre o exemplo associado ao "binômio" Embrapa x Monsanto, eles defendem que o conhecimento seja patenteado e transferido ao movimento social organizado.

Um terceiro grupo pensa diferente em relação à questão dos indicadores. Discordam dos primeiros dizendo que as patentes das universidades públicas dificilmente contribuirão para melhorar a vida dos pobres. E dizem, também para o segundo grupo, que se o objetivo é retribuir com conhecimento aqueles que com o fruto do seu trabalho são os que mais colaboram para que possamos fazer pesquisa em meio a um crescente número de instituições privadas e tendo que contrariar tantos outros interesses, devemos fazer isso diretamente.

Municiar esse debate parece essencial para orientar nossa instituição. E seria desastroso se os resultados alcançados e as metas propostas na Unicamp por aqueles professores primeiramente citados fossem tomados como exemplo a ser emulado por outras universidades públicas brasileiras. Por isso, iremos referir primeiro aos seus argumentos.

Sobre a questão dos indicadores, vale a pena olhar o que ocorre nos EUA, país que é sempre citado como exemplo a emular quando se trata de temas como o que nos ocupa.

\footnotetext{
* Professor Titular do Departamento de Política Científica e Tecnológica da UNICAMP.

** Doutorando do Departamento de Política Científica e Tecnológica da UNICAMP.
} 
Logo de início, é importante frisar algo que é sabido, mas raramente mencionado por eles. Nos EUA a participação das patentes universitárias no total - cerca de 3\% - é quase insignificante, no Brasil, as universidades são responsáveis por 59\%! De fato, entre os anos de 2001 e 2008, elas solicitaram 1.359 patentes contra 933 das empresas.

Essa situação, que se repete em outros países avançados, nos leva a pensar que é inerente ao bom funcionamento do capitalismo o fato de as universidades não gerarem patentes.

$\mathrm{Na}$ verdade, sua contribuição para a inovação e a competitividade das empresas não decorre das patentes que gera. Para a sociedade, que pode por essa via, ainda que com os vazamentos que o capitalismo impõe, ser beneficiada, as patentes tampouco são importantes.

Um fato significativo, mas que nada tem a ver com isso embora seja citado como se tivesse, é a tendência de utilização do conhecimento proveniente de instituições públicas para a geração de patentes por empresas. Tanto nos EUA quanto em outros países avançados, a intensidade de citação de trabalhos científicos nas patentes, embora seja variável (é quase dez vezes maior na área de fármacos do que na de componentes eletrônicos, por exemplo), tem aumentado significativamente.

Mas para proporcionar mais elementos de avaliação, retiramos dentre os muitos que existem na bibliografia sobre o tema três conjuntos de informação lamentavelmente pouco citados pelos que apóiam as iniciativas de "patenteamento nas universidades".

Primeiro: a significativa correlação observada - entre número de trabalhos científicos e patentes - existente nos EUA ao longo do tempo e, numa visão estática, em outros países avançados, não tem porque ser assumida, como nos alerta a Estatística, como causalidade. Na verdade, é outra correlação dinâmica - entre o gasto em P\&D empresarial e patentes -, a que explica causalmente o crescimento das patentes observado nos EUA e naqueles países. O que "de lambuja" explica porque os papers brasileiros não se transformam (e nem é provável que venham a sê-lo) em patentes.

Segundo: as empresas estadunidenses não estão interessadas nas poucas patentes geradas na universidade para obter maiores lucros. $\mathrm{Na}$ realidade, nem sequer estão interessadas nos resultados que a pesquisa universitária pode gerar: apenas $1 \%$ do que a empresa gasta em P\&D é contratado com as universidades. O que "de lambuja" explica o fracasso da experiência dos nossos "Parques e Pólos de Alta Tecnologia" e mostra o quão improvável é a meta de "transferência de conhecimento" da universidade para a empresa perseguida pela Política de C\&T em curso. 
Terceiro: o importante para as empresas de lá não é o conhecimento intangível ou incorporado em patentes, processos ou equipamentos que a universidade pode produzir. É, sim, o conhecimento incorporado em pessoas que, absorvidas pelas empresas, irão realizar a P\&D que garante diferenciais de lucro cada vez mais apoiados em "progresso" tecnológico. Nos EUA, cerca de $70 \%$ dos mestres e doutores que se formam em "ciências duras" e engenharias a cada ano vão fazer pesquisa na empresa privada.

Dado que é assim que a universidade estadunidense através das empresas pode contribuir para a sociedade, cabe indagar o que acontece no Brasil.

Há aqui uma diferença ainda mais gritante do que a de 20 vezes da relação entre os 3\% dos EUA e os 59\% do Brasil referente à participação das patentes universitárias no total.

De fato, no ano que vem o Brasil formará 30 mil mestres e doutores em ciências "duras" e engenharias. Se as empresas contratarem 10\% a mais dos 3 mil que nelas fazem $\mathrm{P} \& \mathrm{D}$, estarão absorvendo apenas $1 \%$ daqueles que serão formados. O que dá, grosso modo, uma relação de 70 vezes!

Voltando ao debate: os que não acreditam que as patentes das universidades brasileiras possam servir para melhorar a vida dos pobres e defendem uma agenda de pesquisa alternativa àquela que os orienta a produzir conhecimento para as empresas, precisam saber que nem mesmo para elas a agenda dominante é importante.

De fato, há muito tempo todos sabemos que as empresas aqui localizadas não demandam conhecimento científico-tecnológico autóctone para serem lucrativas. Nossa condição periférica, com dependência cultural que condiciona um padrão produtivo e tecnológico imitativo e com baixa remuneração da classe trabalhadora que induz, "envia" um sinal de mercado às empresas que determina um comportamento — racional e justificado — avesso à P\&D.

As pesquisas realizadas pelo IBGE - as Pintecs - têm produzido a base empírica que nos faltava para comprovar a veracidade das análises críticas que têm sido feitas desde os anos 60. Dado que temos explorado essa informação em outros artigos, não as repetiremos aqui.

Mas os que querem reorientar a agenda de pesquisa para atender outros atores, como os empreendimentos solidários, os movimentos sociais ou o próprio Estado, podem estar preocupados com o que se poderia deixar de ganhar com a mudança. Para eles, indicamos uma realidade relacionada à Unicamp e outras duas do cenário internacional.

Das 470 patentes solicitadas pela Unicamp ao INPI entre 1989 e 2006, foram obtidos 50 registros. Os quais deram origem em 2006 a 30 contratos de licenciamento 
firmados com 24 empresas, que geram uma receita média anual de $\mathrm{R} \$ 250$ mil. O que corresponde a $0,13 \%$ do orçamento de pesquisa da Universidade e a apenas $0,02 \%$ de seu orçamento total. O que não surpreende se comparamos essa porcentagem com o que significa, do orçamento da universidade estadunidense, aquele $1 \%$ do gasto de $\mathrm{P} \& \mathrm{D}$ da empresa com ela contratada. Ele representa, por casualidade, $1 \%$ do orçamento total da universidade.

Ou seja, as iniciativas de "patenteamento nas universidades" não geram nem mesmo ganhos financeiros de curto prazo para o conjunto da universidade. O que não quer dizer que, tal como ocorre em qualquer área de política pública - sempre um misto de policy e politics -, não beneficiem alguns dos seus segmentos.

É dos EUA a primeira realidade do cenário internacional. O sucesso de algumas grandes universidades na produção de patentes associado às injunções e facilidades do sistema universitário estadunidense, provocou a partir dos anos de 1980 uma "febre" de criação de escritórios de patentes semelhante à que hoje se verifica no Brasil. O resultado tem sido pouco alvissareiro: pesquisa junto a 62 das maiores universidades estadunidenses mostrou que em 60 delas $(97 \%)$ as receitas obtidas com a exploração de patentes foi inferior ao custo de montagem e manutenção dos escritórios.

A outra ocorreu quando a "febre" cruzou a fronteira. O caso mexicano, também bastante mais antigo que o brasileiro, ainda que impressionista, é elucidativo. Em conversas off the record, o encarregado do escritório da UNAM nos anos de 1980 revelou que a grande maioria das patentes que elaborava a pedido dos seus colegas era un agradito para que eles pudessem fazer jus à gratificação que o sistema de merit pay já então implantado concedia aos "pesquisadores inventores".

Apresentados os argumentos que servem para contextualizar a posição daqueles professores que comemoram o "sucesso patenteador" da universidade pública, é necessário um outro esforço: o de dialogar com os que não aceitando a via do "mercado" ressaltam a injustiça que seria deixar que as multinacionais se apossem do conhecimento desenvolvido na universidade.

É uma démarche mais complexa, ainda que mais significativa para a universidade. Ela tem sido abordada em outros trabalhos e não seria adequado retomá-la aqui. Apenas lembraremos que ela está associada a uma questão sistematicamente protelada: qual é a agenda de pesquisa que nos interessa explorar?

Que siga o debate... 